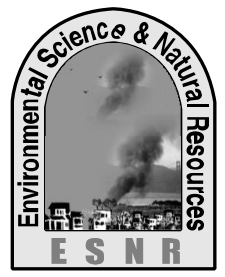

\title{
Prevalence of Seed Borne Fungi Associated with Chickpea Seeds and Biological and Chemical Control of Fusarium oxysporum Causing Wilt Disease
}

\author{
M. D. Hossain ${ }^{1}$, "M. Imran' ${ }^{2}$ K. A. Bhuiyan ${ }^{1}$, M. E. Habib ${ }^{3}$ and M. Ikrum ${ }^{4}$ \\ ${ }^{1}$ Department of Plant Pathology, BSMRAU, Gazipur \\ 2, Department of Environmental Science, BAU, Mymensingh \\ ${ }^{3}$ Centre for Natural Resource Studies (CNRS), Dhaka \\ ${ }^{5}$ Department of Horticulture, BAU, Mymensingh \\ *Corresponding author: imran.pstu@gmail.com
}

\begin{abstract}
A total of 20 chickpea seed samples were collected from BARI, Gazipurand different locations of Savar, Dhaka district. Blotter method was used for detection of the associated fungi of chickpea seeds. Altogether 14 fungi comprising 12 genera namely Aspergillus flavus, Aspergillus niger, Aspergillus sp, Botryodiplodia theobromae, Botryti cinerea, Curvularia lunata, Chaetomium globosum, Cladosporium sp., Colletotrichum dematium, Fusarium oxysporum, Macrophomina phasaelina, Rhizoctonia solani, Rhizopus stolonifer and Stemphylium sarciniforme were isolated from chickpea seed samples. Among the fungi isolated fungi, $F$. oxysporumwas most prevalent with an average incidence of $18.95 \%$ and found in all the seed samples. The germination of seed samples varied from 55-90 \% on blotter. The pathogenic fungi and other storage fungi like Aspergillus caused lower the germination of the seeds.A pathogenicity test was conducted with 20 isolates of $F$. oxysporum against their origin of chickpea seed samples in pot culture. The pathogenecity ranged from weak to highly pathogenic. The isolates FO 19, FO 17, FO 11 and FO 18 were highly virulent. The isolates FO 9, FO10 and FO 15 were virulent and rest of the isolates were moderately virulent. The isolates FO 2 and FO 3 were weak pathogen.
\end{abstract}

Key words: Pathogenicity test, Fungal diseases, Biological control, Wilt diseases, Fusarium oxysporum

\section{Introduction}

Chickpea (Cicerarietinum L.) is a high protein food crop in many areas of the world. It is one of the major pulse crop both in terms of area coverage and production in Bangladesh. In 2000-01, area covered by chickpea was more than 40 thousand acre with the production of 12 thousand tons (Anon.2004). It contributes about $20 \%$ of the total pulses grown in the country. It plays a vital role in human and animal nutrition, having $20.8 \%$ protein which is $100 \%$ edible (Gowda and Kaul, 1982).Several diseases caused by several pathogens have been described on chickpeas. A total of 172 pathogens consisting of fungi, bacteria, nematode, viruses and mycoplasma-like organisms have been recorded on chickpea all over the world. Among them Fusariumoxysporum is the most destructive pathogen causing wilt disease (Nene et al. 1996). The pathogen is soil and seed borne and can survive in the residual stubbles for more than three years (Nene et al. 1981). The other important diseases are collar rot (sclerotiumrolfsii), dry root rot (Rhizoctoniasolani), and botrytis gray mold (Botrytis cinerea).

Wilt is prevalent almost all the chickpea growing countries of the world (Rahman and Ahmed 1985). The disease is widespread in the chickpea-growing areas of Bangladesh. Chickpea wilt significantly limits the chickpea production (Nene and Haware 1980). The disease causes considerable yield loss (Jalali and Chand 1992). Although no precise information is available on the extent of damage by the disease, a rough estimate of $10 \%$ loss has been considered to be a regular feature in the chickpea growing state of India (Singh and Dahiya 1973). In Bangladesh seasonal observations have shown much higher incidence of the diseases (Bakr 1991). For the control of these diseases a limited work has been done in Bangladesh. Though some effective fungicides are available in the market, they are only for chemical control. Some works about chemical control recently have been done (Ahmed 1985a and 1985b), but works about biological control are not available. However, these fungi are soil-borne and biological control may be suitable against them. It is attractive in an environmental and economic sense on account of offering durable, safe and cost-effective means to control the diseases as an alternative to chemicals (Merriman and Russell 1990).

Trichodermaspp. are well known for their antagonistic effect against many soil-borne fungi (Strashnow et al. 1985). Now-a-days many Trichodermaharzianum is registered for use against damping off in Israel. During the past several years some notable success of diseases control was achieved through the introduction of antagonistic microorganism like Trichoderma both in vitro and in vivo (Sundar et al., 1995). In a pot culture study Khan (2003) found Trichoderma was very 
effective against seedling mortality of chickpea caused by Sclerotiumrolfsii. There are also some plant extracts which have micro-cidal qualities, antagonistic to some pathogens (Hossain et al., 1993).

There is no detail information on the infection of the seed-borne fungi including $F$. oxysporum causing chickpea wilt associated with chickpea seeds. Only a limited work has been done on the prevalence of seedborne pathogen on chickpea.

Considering the above facts, the present piece of research was undertaken with the following objectives:

(1) To determine the prevalence of fungi associated with Chickpea seeds.

(2) To determine the effectiveness of fungicides, Trichoderma as a bio-control agent and plant extracts against Fusariumoxysporum.

\section{Materials and Methods}

\section{Prevalence of seed borne fungi of chickpea Collection of seed samples}

A total of 20 seed samples were collected from different location of Gazipur and Dhaka districts during April 2005. Among the collected samples, BARI-1, BARI-2, BARI-3, BARI-4, BARI-5, BARI-6, BARI-7 and BARI-8 were collected from Bangladesh Agricultural Research Institute. Five local varieties viz. LJP-1, LJP-2, LJP-3, LJP-4 and LJP-5 were collected from the farmers of Gazipur and seven local varieties namely LSV-1, LSV-2, LSV-3, LSV-4, LSV-5, LSV-6 and LSV-7 were collected from the farmers of Savar, Dhaka. The seeds were brought to the Plant Pathology Laboratory of BSMRAU and preserved at $10 \mathrm{C}$ for subsequent studies.

\section{Pathogenicity test of Fusariumoxysporum against chickpea plants}

Twenty isolates of $F$. oxysporumwere randomly selected from each of the studied chickpea seed sample. The selected isolates of $F$. oxysporum were cultured on PDA medium and transferred to PDA slants and kept at $10^{\circ} \mathrm{C}$ temperature for further use.

\section{Screening of Trichoderma spp. against F. oxysporum}

Trichoderma isolates were collected and isolated from the rhizosphere and rhizoplane of different crops by soil dilution plate method as described by Dhingra and
Sinclair (1985) and root washing method as stated by Hyakumachi (1994). In dilution plate technique $10 \mathrm{~g}$ of composite soil collected from rhizosphere and rhizoplane of the selected plant species were taken in a $250 \mathrm{ml}$ Erlenmeyer flask. Sterilized water was added to flasks at $100 \mathrm{ml} /$ flask. The flasks were agitated on a vortex for 2 minutes for thorough mixing and $1 \mathrm{ml} \mathrm{sub}$ sample was transferred from each flask to another flasks containing $9 \mathrm{ml}$ sterile water. In this way a 5fold serial dilution of the soil suspension was prepared. Based on the colony characters and spore morphology following standard key colonies of Trichoderma spp. grown on the plates was identified. Isolates of Trichodermasp. grown on the plates were purified in acidified water agar ( $\mathrm{pH}$ 5.0) using hyphal tip culture technique. The identified isolates of Trichodermawere transferred to PDA slants and kept at $10^{\circ} \mathrm{C}$ for further use.

$\begin{array}{lllll}\begin{array}{l}\text { Screening of } \\ \text { oxysporum }\end{array} & \text { Trichoderma isolate against } & \boldsymbol{F} \text {. } \\ \text { Antagonism } & \text { between } & \text { each } & \text { of } & \text { the }\end{array}$
Trichodermaharzianum isolate from rhizosphere or rhizoplane and $F$. oxysporumwere determined by following dual plate culture technique (Dhingra and Sinclair 1985). An in-vitro study was carried out find out the antagonistic effect of 15 selected $T$. harzianum isolates against $F$. oxysporumon PDA by dual culture technique. The PDA containing extract of $200 \mathrm{~g}$ peeled potato, $20 \mathrm{~g}$ dextrose and $17 \mathrm{~g}$ agar per litre of water. Discs of mycelium (5mm diameter) of each of the isolates of T.harzianumand $F$. oxysporumwere cut from the edge of an actively growing colony with a cork borer (5 $\mathrm{mm}$ diameter). Two discs of each isolate were placed at the edges of each PDA plate and one disc of $F$. oxysporumwas placed in the centre. The plates only with the discs of F. oxysporum in the center were used as control plate. The plates were then incubated at room temperature until the mycelium of $F$. oxysporumcovered the whole plate. The arms and height of the colonies were measured after the complete growth of the control plates. There after inhibition percentages of the $F$. oxysporumwere calculated based on the growth of the pathogen on PDA plates in absence of antagonistic fungal isolates following the formula as suggested by Sundaret al. (1995).

$$
\% \text { Inhibition }=\frac{X-Y}{X} \times 100
$$

Where,

$\mathrm{X}=$ Mycelial growth of the pathogen ( $F$. oxysporum $)$ in absence of antagonist i.e. control

$\mathrm{Y}=$ Mycelial growth of the pathogen ( $F$. oxysporum) in presence of antagonist. 
The plates were arranged in Completely Randomized Design (CRD) with three replications. Isolates were classified accordingly on the basis of inhibiting potentiality after 7 days of incubation. The fungal isolates which inhibited around $75-90 \%$ absolute inhibition of $F$. oxysporum were grouped as very strong, $60-75 \%$ inhibition of $F$. oxysporum were grouped as strong, 50-60\% inhibition of $F$. oxysporum were grouped as moderate, $30-50 \%$ inhibition of $F$. oxysporum were grouped as weak, $15-30 \%$ inhibition of $F$. oxysporum were grouped as very weak, and 0$15 \%$ inhibition of $F$. oxysporum were grouped as no inhibition. Isolate having strong suppressive affect on mycelial growth of $F$. oxysporum were selected for further study.

\section{Laboratory evaluation of fungicides on the radial growth F. oxysporum}

\section{Selection of fungicides}

Four fungicides namely- Bavistin, Vitavax-200, Cupravit and Dithane M-45 were tested in-vitro to evaluate their effect on colony growth of $F$. oxysporum following poison food technique (Dhingra and Sinclair 1985). All the tested fungicides were used at three different concentrations viz. 100, 200 and 400 ppm. The details of the fungicides are presented in the Table 1.

\section{Effect of fungicides on radial growth of $F$. oxysporum}

The effect of fungicides on the radial growth of $F$. oxysporum was determined on PDA medium. PDA was prepared by mixing infusion of $200 \mathrm{~g}$ peeled potato, $20 \mathrm{~g}$ dextrose and $17 \mathrm{~g}$ agar in $1000 \mathrm{ml}$ distilled water. The medium was cooked properly and poured into conical flasks at $100 \mathrm{ml}$ per flask. Before solidification, requisite quantity of individual fungicide was added to the medium to have concentrations of 100, 200 and 400 ppm. After thorough mixing with fungicides, the medium was autoclaved at $121^{\circ} \mathrm{C}$ under $1.1 \mathrm{~kg} / \mathrm{cm}^{2}$ pressure for 20 minutes. Approximately $20 \mathrm{ml}$ of melted PDA mixed with fungicides was poured into each $90 \mathrm{~mm}$ petridish.

After solidification, the plates were inoculated by $5 \mathrm{~mm}$ discs of 3 days old PDA cultures of $F$. oxysporum. Three replicated PDA plates received no fungicide were also inoculated as control. The inoculated plates were incubated at $27 \mathrm{C}$ and data on radial growth was taken after $60 \mathrm{hrs}$ of inoculation. Diameter of the colonies on PDA with and without fungicide was measured from the bottom side of the petridishes. Inhibition of radial growth was computed based on colony diameter on control plate using the following formula shown below (Sundaret al. 1995).

$$
\% \text { Inhibition }=\frac{\mathrm{X}-\mathrm{Y}}{\mathrm{X}} \times 100
$$

Where, $\mathrm{X}=$ radial growth of control plates. $\mathrm{Y}=$ radial growth on fungicide treated plates.

Table 1. Details of fungicides used in the present study

\begin{tabular}{|l|c|l|c|}
\hline Trade name & Common name & Chemical name & $\begin{array}{c}\text { Active } \\
\text { ingredient }(\%)\end{array}$ \\
\hline Bavistin & Carbendazim & Methyl-benzimidazole-2-thiocarbamate & 50 \\
\hline Vitavax-200 & Carboxin & 5,6-dihydro-2-methyl-1,4-oxathin-3-carboxanilide & 75 \\
\hline Cupravit & Copper oxychloride & & 50 \\
\hline Dithane M-45 & Mancozeb & Manganese ethylenebisdithiocarbamate & 80 \\
\hline
\end{tabular}

\section{Effect of fungicide on mycelial dry weight}

To determine the effect of the fungicides on mycelial dry weight of $F$. oxysporum, potato dextrose (PD) broth was used. The medium was prepared by mixing infusion of $200 \mathrm{~g}$ peeled potato; $20 \mathrm{~g}$ dextrose in $1000 \mathrm{ml}$ distilled water. After cooking the medium was poured into $250 \mathrm{ml}$ conical flask at the rate of $100 \mathrm{ml}$ per flask. Requisite quantity of each fungicide was added to the broth to have concentrations of 100, 200 and $400 \mathrm{ppm}$. Three replicated flasks were used for each dose of the four fungicides. The contents of the flasks were autoclaved at $121^{0} \mathrm{C}$ under $1 \mathrm{~kg} / \mathrm{cm}^{2}$ for 20 minutes. The flasks were placed inside a clean bench for cooling ambient temperature. The flasks were inoculated with mycelial discs of 5 days old $F$. oysporum cultured on PDA. The discs were cut with a flame sterilized cork borer $(5 \mathrm{~mm})$. Inoculation was done by putting one mycelial disc per flask with a flame-sterilized needle. Additional three flasks containing the PD broth receiving no fungicides were used as control. The inoculated flasks were incubated at room temperature $(27 \mathrm{C})$ for 14 days. At the end of incubation, the cultures in all flasks were filtered separately through pre-weighted filter paper. Dry 
weight of mycelium was determined after drying the mycelium on filter paper in an oven at $70 \mathrm{C}$ for 12 hours. Dry weight of mycelium was obtained by subtracting weight of filter paper from weight of filter paper and mycelium. Inhibition of mycelial dry weight was determined by comparing the growth in control flasks following the formula mentioned earlier.

\section{Effect of plant extracts on the growth of Fusarium oxysporum}

\section{Effect on radial growth of Fusarium oxysporum}

An in-vitro test was conducted to determine the effect of plant extracts on radial colony growth of $F$. oxysporumfollowing poison food technique as described by Begum and Bhuiyan (2004). After solidification, the plates were inoculated by placing 5 mm discs of 3 days old PDA cultures of $F$. oxysporum. The discs were cut with flame sterilized cork borer ( 5 $\mathrm{mm}$ diameter). The inocula were placed at the center of the test plates using a flame- sterilized needle at one disc per plate. Three replicated plates were used for each concentration of every plant extract. Three plates received no extracts were used as control. The inoculated plates were incubated at $28 \mathrm{C}$ and data on radial colony diameter was recorded after 5 days of incubation. Inhibition of radial growth was computed based on colony diameter on control plate using the same formula (Sundar et al. 1995) as described earlier.

\section{Effect on mycelial dry weight}

To determine the effect of the plant extractson mycelial dry weight of $F$. oxysporum potato dextrose (PD) broth was used. The medium was prepared by mixing infusion of $200 \mathrm{~g}$ peeled potato; $20 \mathrm{~g}$ dextrose in $1000 \mathrm{ml}$ distilled water. After cooking the medium was poured into $250 \mathrm{ml}$ conical flask at the rate of 100 $\mathrm{ml}$ per flask. Requisite quantity of each plant extracts was added to the broth to have concentration of 5,10 , $20 \%$. Three replicated flasks were used for each concentration of the plant extracts. The contents of the flasks were autoclaved at $121 \mathrm{C}$ under $1 \mathrm{~kg} / \mathrm{cm}^{2}$ for 20 minutes. The flasks were placed inside a clean bench for cooling ambient temperature. The flasks were inoculated with mycelial discs of 5 dayô old PDAculture of $F$. oxysporum.Similar procedure has been followed for taking the mycelial dry weightas stated earlier.

\section{Experimental design and data analysis}

The experiments were conducted in the plant pathology laboratory of BSMRAU with three replications of each treatment following Completely Randomized Design (CRD). Data were analyzed by using MSTAT- C program. The significant difference, if any, among the means were compared by Duncanôs Multiple Range Test (DMRT). Whenever necessary the data were transformed before statistical analysis following appropriate method.

\section{Results and Discusion}

Prevalence of seed borne fungi of Chickpea

Altogether 14 fungi comprising 12 genera namely Aspergillus flavus, Aspergillus niger, Aspergillus sp, Botryodiplodia theobromae, Botryticinerea, Curvularialunata, Chaetomium globosum, Cladosporium sp., Colletotrichumdematium, Fusarium oxysporum, Macrophomina phasaelina, Rhizoctonia solani, Rhizopus stolonifer and Stemphyliums arciniforme were isolated chickpea seed samples (Table 1).

Among the fungi isolated A. flavus, $F$. oxysporum, Aspergillussp, C. globosum, C. dematium and $M$. phasaelinawere prevalent in all the tested seed samples. The most prevalent funguswas A. flavus followed by F.oxysporum, Aspergillussp, C. globosum, C. dematium, M. phasaelina,A. niger, S. sarciniforme, $B$. cinerea, $R$. solani and $R$. stolonifer with an average incidence of $18.95,18.55,15.20,11.35,7.60,6.80$, $6.70,6.50,6.00,5.95$, and $4.50 \%$, respectively. The average prevalence of Cladosporium sp. and C. lunata was only 1.25 and $0.55 \%$, respectively.

In blotter test, the germination of seed samples varied from $55-90 \%$. The highest germination of $90 \%$ was recorded on seed sample BARI -3 where the most pathogenic and other fungi were either absent or present in a fewer number. The lowest germination was recorded in the seed sample LSV-3from Savar of Dhaka district in which the incidences of pathogenic fungi and other fungi were present dominantly. It has been clearly evident that not only the pathogenic fungi but also the presence of the storage fungi like Aspergillus caused lowers the germination of the seeds. Where the prevalence of fungi was higher, germination percentage of the seed was lower. 
Table 2. Percent prevalence of different seed borne fungi associated with chickpea seeds

\begin{tabular}{|c|c|c|c|c|c|c|c|c|c|c|c|c|c|c|c|}
\hline & 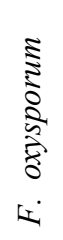 & 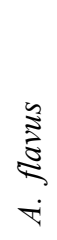 & 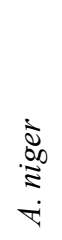 & 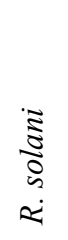 & 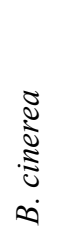 & $\begin{array}{l}\stackrel{\Xi}{\Xi} \\
\vdots \\
\vdots \\
ن\end{array}$ & 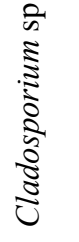 & 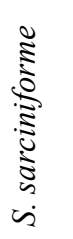 & 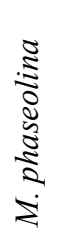 & $\begin{array}{l}\tilde{5} \\
5 \\
0 \\
0 \\
0 \\
0 \\
ن\end{array}$ & 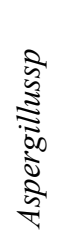 & 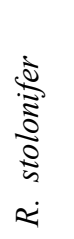 & 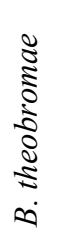 & 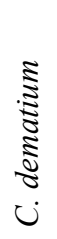 & 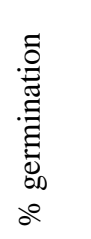 \\
\hline BARI-1 & 10 & 12 & 10 & 1 & 4 & 0 & 5 & 0 & 4 & 7 & 19 & 8 & 5 & 6 & 81 \\
\hline BARI-2 & 4 & 21 & 6 & 7 & 6 & 0 & 0 & 7 & 7 & 10 & 11 & 5 & 0 & 8 & 87 \\
\hline BARI-3 & 2 & 13 & 8 & 4 & 5 & 0 & 0 & 5 & 4 & 6 & 14 & 6 & 0 & 4 & 90 \\
\hline $\begin{array}{l}\text { BA } \\
\text { RI-4 }\end{array}$ & 5 & 24 & 5 & 5 & 7 & 4 & 0 & 4 & 6 & 9 & 5 & 9 & 0 & 5 & 80 \\
\hline BARI-5 & 19 & 26 & 1 & 8 & 5 & 0 & 0 & 5 & 7 & 9 & 9 & 0 & 0 & 4 & 71 \\
\hline BARI-6 & 24 & 15 & 17 & 10 & 5 & 0 & 0 & 11 & 8 & 14 & 14 & 0 & 0 & 7 & 63 \\
\hline BARI-7 & 17 & 9 & 13 & 3 & 0 & 2 & 2 & 0 & 2 & 7 & 22 & 3 & 0 & 3 & 75 \\
\hline BARI-8 & 20 & 22 & 18 & 10 & 5 & 0 & 0 & 9 & 0 & 14 & 11 & 0 & 0 & 11 & 60 \\
\hline LJP-1 & 28 & 25 & 10 & 7 & 7 & 0 & 0 & 3 & 6 & 9 & 27 & 0 & 0 & 5 & 58 \\
\hline LJP-2 & 23 & 24 & 0 & 6 & 5 & 0 & 0 & 4 & 2 & 10 & 10 & 1 & 10 & 6 & 70 \\
\hline LJP-3 & 15 & 19 & 5 & 4 & 7 & 0 & 0 & 9 & 8 & 12 & 17 & 8 & 0 & 7 & 81 \\
\hline LJP-4 & 21 & 27 & 0 & 8 & 7 & 0 & 0 & 4 & 8 & 13 & 19 & 9 & 0 & 10 & 74 \\
\hline LJP-5 & 26 & 14 & 2 & 8 & 9 & 0 & 0 & 6 & 10 & 12 & 9 & 7 & 0 & 13 & 72 \\
\hline LSV-1 & 17 & 13 & 8 & 2 & 5 & 0 & 2 & 7 & 9 & 10 & 12 & 8 & 3 & 9 & 85 \\
\hline LSV-2 & 25 & 10 & 5 & 9 & 8 & 0 & 0 & 5 & 11 & 13 & 17 & 6 & 0 & 9 & 75 \\
\hline LSV-3 & 29 & 36 & 6 & 0 & 2 & 5 & 0 & 10 & 7 & 15 & 21 & 0 & 5 & 10 & 55 \\
\hline LSV-4 & 27 & 12 & 0 & 9 & 9 & 0 & 0 & 11 & 12 & 14 & 19 & 10 & 0 & 13 & 60 \\
\hline LSV-5 & 20 & 25 & 11 & 4 & 4 & 0 & 0 & 10 & 5 & 18 & 13 & 3 & 0 & 5 & 69 \\
\hline LSV-6 & 23 & 13 & 3 & 2 & 10 & 0 & 1 & 11 & 9 & 12 & 15 & 0 & 0 & 10 & 72 \\
\hline LSV-7 & 16 & 19 & 6 & 2 & 10 & 0 & 0 & 9 & 11 & 13 & 10 & 7 & 0 & 7 & 85 \\
\hline Mean & 18. & $\begin{array}{l}18 . \\
95\end{array}$ & 6.7 & $\begin{array}{l}5.9 \\
5\end{array}$ & $\begin{array}{l}6.0 \\
0\end{array}$ & 0.55 & 0.50 & 6.50 & $\begin{array}{l}6.8 \\
0\end{array}$ & $\begin{array}{l}11.3 \\
5\end{array}$ & $\begin{array}{l}15.2 \\
0\end{array}$ & 4.50 & $\begin{array}{l}1.2 \\
5\end{array}$ & $\begin{array}{l}7.6 \\
0\end{array}$ & 73.15 \\
\hline
\end{tabular}

Pathogenicity test of $F$. oxysporumon Chickpea seedlings

The results of pathogenicity test of $F$. oxysporumagainst chickpea seedlings are presented in the Table 3 and Plate I. Among the tested isolates of $F$. oxysporum, the highest seedling mortality was observed with the isolate FO 19 followed by the isolates FO 17, FO 11 and FO 18 which were highly virulent. The isolates FO 9, FO10 and FO 15were virulent and rest of the isolates the isolates were moderately virulent except for the isolates FO 2 and
FO 3 which were weak pathogen. The lowest infection $6.66 \%$ was recorded with the isolate FO 3 . Among the tested isolates, no isolate of $F$. oxysporum was found to be avirulent.

In fact, it is difficult to conclude about the degree of virulence as only single method of inoculation has been used and observation was also done for shorter period in pot culture. In the field condition with different methods of inoculation the degree of virulence of the isolates may be varied greatly. 
Table 3. Pathogenicity test of Fusarium oxysporum isolates

\begin{tabular}{l|l|l|l|l|}
\hline $\begin{array}{l}\text { Isolates } \\
\text { of } \text { F. } \text { oxysporum }\end{array}$ & Variety/Genotype & $\begin{array}{l}\text { Designation } \\
\text { seed sample }\end{array}$ & of & Location \\
infected \\
\hline FO1 & BARI-1 & BARI-1 & BARI, Joydevpur & 53.33 \\
FO2 & BARI-2 & BARI-2 & BARI, Joydevpur & 6.66 \\
FO3 & BARI-3 & BARI-3 & BARI, Joydevpur & 13.32 \\
FO4 & BARI-4 & BARI-4 & BARI, Joydevpur & 6.66 \\
FO5 & BARI-5 & BARI-5 & BARI, Joydevpur & 39.99 \\
FO6 & BARI-6 & BARI-6 & BARI, Joydevpur & 42.22 \\
FO7 & BARI-7 & BARI-7 & BARI, Joydevpur & 37.77 \\
FO8 & BARI-8 & BARI-8 & BARI, Joydevpur & 59.99 \\
FO9 & Local & LJP-1 & Joydevpur, Gazipur & 71.10 \\
FO10 & Local & LJP-2 & Joydevpur, Gazipur & 77.78 \\
FO11 & Local & LJP-3 & Joydevpur, Gazipur & 84.44 \\
FO12 & Local & LJP-4 & Joydevpur, Gazipur & 64.44 \\
FO13 & Local & LJP-5 & Savar, Dhaka & 66.66 \\
FO14 & LSV-1 & Savar, Dhaka & 55.55 \\
FO15 & Local & LSV-2 & Savar, Dhaka & 73.33 \\
FO16 & Local & LSV-3 & Savar, Dhaka & 39.99 \\
FO17 & Local & LSV-4 & Savar, Dhaka & 86.66 \\
FO18 & Local & LSV-5 & Savar, Dhaka & 79.99 \\
FO19 & Local & LSV-6 & & 91.10 \\
FO20 & Local & LSV-7 & 64.44 \\
\hline
\end{tabular}

\section{Screening of Trichoderma harzianum isolates against F. oxysporum}

Cultural characteristics and screening of Trichoderma isolates

A total of 15 fungal isolates collected from the rhizosphere of different crops by soil dilution plate method and root washing methods were identified as Trichodermaharzianum. These Trichodermaharzianum were tested against $F$. oxysporum and the results were presented in table 4 and plate II. The colony color of the isolated T.harzianum isolates were variable from light green to dark green with moderate to profuse mycelial growth and minimum sporulation to profuse sporulation. The colony colour, mycelia, conidiophore and conidia/spore were the typical characteristics of Trichodermaharzianum as stated by Barnett (1980).
Effect of Trichoderma isolates was observed on the reduction of growth of $F$. oxysporum as compared to control, which did not receive antagonistic fungi. Among the isolates, T8 showed the highest growth inhibition $(82.55 \%)$ of $F$. oxysporum followed by T13 (73.00\%), T11 (71.65\%) and T13 (68.61\%) inhibition. Isolate $\mathrm{T} 15$ showed the lowest growth reduction $(35.16 \%)$ of $F$. oxysporum followed by isolates T4 $(41.93 \%)$.

Result of the experiment showed that most of the tested isolates were effective to inhibit mycelial growth of $F$. oxysporumon culture media. Similar observations were also reported by other investigators (Eladet al, 1982, Akther1999 and Mondal 1999). 
Table 4. Cultural characteristics and screening of Trichoderma isolates against Fusarium oxysporum.

\begin{tabular}{|c|c|c|c|c|c|}
\hline $\begin{array}{c}\text { Trichoderma } \\
\text { isolates }\end{array}$ & $\begin{array}{l}\text { Source of the } \\
\text { isolates }\end{array}$ & Colony colour & $\begin{array}{l}\text { Mycelial } \\
\text { growth* }\end{array}$ & Sporulation** & $\%$ Inhibition \\
\hline $\mathrm{T} 1$ & Mung bean & Green & + & ++ & 53.55 \\
\hline $\mathrm{T} 2$ & Okra & green & + & + & 53.55 \\
\hline $\mathrm{T} 3$ & Chilli & Light green & ++ & +++ & 55.84 \\
\hline $\mathrm{T} 4$ & Yard long bean & green & ++ & +++ & 41.93 \\
\hline T5 & Dhuincha & Light green & ++ & ++ & 73.00 \\
\hline T6 & Snake Gourd & green & + & + & 70.18 \\
\hline $\mathrm{T} 7$ & Mesta & Light green & ++ & ++ & 51.52 \\
\hline $\mathrm{T} 8$ & Rice & Dark green & +++ & +++ & 82.55 \\
\hline T9 & Red amaranth & Green & + & + & 47.47 \\
\hline $\mathrm{T} 10$ & Tomato & Green & ++ & ++ & 56.43 \\
\hline $\mathrm{T} 11$ & Brinjal & Green & + & +++ & 71.65 \\
\hline $\mathrm{T} 12$ & Okra & Green & ++ & + & 55.36 \\
\hline $\mathrm{T} 13$ & Bottle gourd & Dark Green & ++ & +++ & 68.61 \\
\hline $\mathrm{T} 14$ & Snake gourd & Light & ++ & ++ & 25.40 \\
\hline $\mathrm{T} 15$ & Jute & Green & ++ & +++ & 35.16 \\
\hline Control(PDA) & & & +++ & +++ & $90.00 \mathrm{~mm}$ \\
\hline
\end{tabular}

$* \quad+,++,+++$ indicates minimum, moderate and profuse mycelial growth.

$* *+,++,+++$ indicates minimum, moderate and profuse sporulation.

Laboratory evaluation of fungicides against Fusarium oxysporum

\section{Radial growth}

The results of the laboratory evaluation of fungicides on the radial growth of Fusariumoxysporumisolate FO 11 are presented in Table 5 and Plate III. The results of the experiment showed that all the selected concentrations of Bavistin 50 WP completely inhibited the radial growth of the tested pathogen.Cupravitshowed the lowest inhibition (19.39) of mycelial growth at 100ppm concentration. At 200 and 400ppm concentrations $25.53 \%$ and $33.65 \%$ reduction of mycelial growth were achieved. Vitavax 200 inhibits 59.76, 70.96 and $74.74 \%$ radial growth of F. oxysporum at 100ppm, 200ppm and 400ppm concentrations respectively. Dithane M 45 showed $26.48,29.32$ and $36.48 \%$ inhibition of radial growth at $100 \mathrm{ppm}, 200 \mathrm{ppm}$ and 400ppm concentration, respectively. Among the tested fungicides, Bavistin 50 WPappeared to be best in inhibiting the hyphal growth of the pathogen $F$. oxysporum in all the concentration. Vitavax 200 was also effective in controlling radial growth of the pathogen but significantly inferior to Bavistin 50 WP at all the concentrations.Cupravit and Dithane M 45 were found to be significantly inferior to Bavistin 50 WP and Vitavax 200 in inhibiting the radial growth of $F$. oxysporum

\section{Mycelial dry weight}

Response of fungicide on mycelial dry weight represent in the table 5. Complete inhibition of mycelial dry weight $(100 \%)$ of $F$. oxysporum was observed at all the concentrations ofBavistin 50 WP.Cupravit showed the lowest inhibition (19.39) of mycelial growth at 100ppm concentration. At 200 and 400ppm concentrations $25.53 \%$ and $33.65 \%$ reduction of mycelial growth were achieved. Vitavax 200 inhibits 59.76, 70.96 and $74.74 \%$ radial growth of $F$. oxysporum at 100ppm, 200ppm and 400ppm concentrations respectively. Dithane M 45 showed $26.48,29.32$ and $36.48 \%$ inhibition of radial growth at $100 \mathrm{ppm}$, 200ppm and 400ppm concentration, respectively. 
Table 5. Effect of fungicides on the growth of Fusarium oxysporum.

\begin{tabular}{|l|c|c|c|}
\hline \multirow{2}{*}{ Fungicides } & Concentration $(\mathrm{ppm})$ & \multicolumn{2}{|c|}{ \% Inhibition } \\
\cline { 2 - 4 } & & Radial growth & Mycelial dry weight \\
\cline { 2 - 4 } & 100 & $100.00 \mathrm{~A}$ & $100.00 \mathrm{~A}$ \\
\cline { 2 - 4 } & 200 & $100.00 \mathrm{~A}$ & $100.00 \mathrm{~A}$ \\
\cline { 2 - 4 } & 400 & $100.00 \mathrm{~A}$ & $100.00 \mathrm{~A}$ \\
\hline \multirow{3}{*}{ Vitavistin 50WP } & 100 & $56.49 \mathrm{D}$ & $70.76 \mathrm{D}$ \\
\cline { 2 - 4 } & 200 & $66.55 \mathrm{C}$ & $74.74 \mathrm{~B}$ \\
\hline \multirow{3}{*}{ Cupravit } & 400 & $71.60 \mathrm{~B}$ & $19.39 \mathrm{I}$ \\
\cline { 2 - 4 } & 100 & $17.74 \mathrm{I}$ & $25.53 \mathrm{H}$ \\
\hline Dithane M-45 & 200 & $24.64 \mathrm{H}$ & $33.65 \mathrm{~F}$ \\
\cline { 2 - 4 } & 400 & $31.52 \mathrm{~F}$ & $26.48 \mathrm{H}$ \\
\cline { 2 - 4 } & 100 & $25.44 \mathrm{H}$ & $29.32 \mathrm{G}$ \\
\hline Control & 200 & $34.32 \mathrm{G}$ & $36.48 \mathrm{E}$ \\
\hline
\end{tabular}

Effect of plant extracts on the growth of $F$. oxysporum

The results of the effect of selected PDA amended plant extracts on the growth of $F$. oxysporum are presented in the Table 6 and Plate IV. The highest reduction $64.08 \%$ and $65.36 \%$ was achieved when PDA amended with garlic extract at $20 \%$ concentration in radial colony diameter and mycelium dry weight of $F$. oxysporum, respectively. The second highest reduction of $39.25 \%$ in radial colony growth was obtained with $20 \%$ neem extract and $40.41 \%$ in mycelium dry weight was attained with $10 \%$ garlic extract. Onion extract gave significantly lower reduction of radial colony growth and mycelial dry weight at all the concentrations in comparison to other extract.
A considerable inhibition of growth was observed with ginger extract. The highest concentration of ginger extract gave statically similar inhibition to the highest concentration of neem extract for both the radial colony growth and mycelial dry weight. In case of all the tested plant extracts the rate of reduction was significantly increased with increasing its concentrations except for neem extract where the inhibition of growth of the two higher concentrations was statistically similar. Result of the experiment showed that the most effective material is garlic, which was followed by neem, ginger and onion.

Extract of garlic was reported to be most effective in inhibiting mycelial growth and spore germination of Fusarium spp. by other scientists. The results of the present study are in partial agreement with the findings of above mentioned workers.

Table 6. Effect of plant extracts on the growth of Fusarium oxysporum

\begin{tabular}{|c|c|c|c|}
\hline \multirow[t]{2}{*}{ Plant extracts } & \multirow[t]{2}{*}{ Concentration $(\% \mathrm{~W} / \mathrm{V})$} & \multicolumn{2}{|c|}{$\%$ Inhibition } \\
\hline & & Radial growth & Mycelial dry weight \\
\hline \multirow[t]{3}{*}{ Onion } & 5 & $17.05 \mathrm{G}^{*}$ & $8.51 \mathrm{H}$ \\
\hline & 10 & $20.27 \mathrm{~F}$ & $12.48 \mathrm{FG}$ \\
\hline & 20 & $24.59 \mathrm{E}$ & $15.44 \mathrm{~F}$ \\
\hline \multirow[t]{3}{*}{ Ginger } & 5 & $27.34 \mathrm{D}$ & $19.53 \mathrm{E}$ \\
\hline & 10 & $32.50 \mathrm{C}$ & $24.42 \mathrm{D}$ \\
\hline & 20 & $36.68 \mathrm{~B}$ & $31.40 \mathrm{C}$ \\
\hline \multirow{3}{*}{ Garlic } & 5 & $18.36 \mathrm{FG}$ & $10.30 \mathrm{GH}$ \\
\hline & 10 & $37.79 \mathrm{~B}$ & $40.41 \mathrm{~B}$ \\
\hline & 20 & $64.08 \mathrm{~A}$ & $65.36 \mathrm{~A}$ \\
\hline \multirow[t]{3}{*}{ Neem } & 5 & $33.64 \mathrm{C}$ & $23.93 \mathrm{D}$ \\
\hline & 10 & $37.99 \mathrm{~B}$ & $30.24 \mathrm{C}$ \\
\hline & 20 & $39.25 \mathrm{~B}$ & $33.31 \mathrm{C}$ \\
\hline Control & & $82.00 \mathrm{~mm}$ & $0.30 \mathrm{~g}$ \\
\hline
\end{tabular}

* Same letter do not differ significantly at 5\% level of significance. 


\section{Conclusions}

Among the fungi isolated A. flavus, F.oxysporum, Aspergillus sp, C. globosum, C. dematium and $M$. phasaelina were prevalent in all the tested seed samples. The most prevalent pathogenic fungus $F$. oxysporum with an average incidence of $18.95 \%$ was found in all the tested 20 seed samples. In blotter test, the germination of seed samples varied from 55-90\%. It has been clearly evident that not only the pathogenic fungi but also the presence of the storage fungi like Aspergillus caused lowers the germination of the seeds.

A pathogenicity test was performed with 20 isolates of $F$. oxysporum against their origin of chickpea seed samples in pot culture. All the tested isolates were pathogenic. Among the tested isolates of $F$. oxysporum, the highest infection was observed with the isolate FO 19 followed by the isolates FO 17, FO 11 and FO 18 which were highly virulent. The isolates FO 9, FO10 and FO 15 were virulent and rest of the isolates the isolates were moderately virulent except for the isolates FO 2 and FO 3 which were weak pathogen. The lowest infection $6.66 \%$ was recorded with the isolate FO 3. No isolate of $F$. oxysporum was found to be avirulent.

A total of 15T. harzianum isolates collected from rhizosphere and rhizoplane of different crops were screened against $F$. oxysporum following dual plate culture technique. The highest $82.55 \%$ growth inhibition of $F$. oxysporum was observed with the isolate T8followed by T13 (73.00\%), T11 (71.65\%) and $\mathrm{T} 13$ (68.61\%). The lowest growth reduction $35.16 \%$ of $F$. oxysporum was recorded with the isolate T15 followed by isolate T4 (41.93\%).

Four fungicides namely Bavistin 50 WP, Vitavax-200, Cupravit, and Dithane M-45 were evaluated in the laboratory at 100, 200 and $400 \mathrm{ppm}$ for their efficacy against the radial colony growth and mycelial dry weight of $F$. oxysporum. The complete inhibition was obtained with Bavistin 50 WP at all the selected concentrations. Vitavax 200 was also effective in controlling radial growth of the pathogen but significantly inferior to Bavistin $50 \mathrm{WP}$ at all the concentrations. Cupravit and Dithane M 45 were found to be significantly inferior to Bavistin $50 \mathrm{WP}$ and Vitavax 200 in inhibiting the radial growth of $F$. oxysporum. Cupravit showed as the least effective in the inhibition of both radial colony and mycelial growths at all the concentrations.

Plant extracts of garlic, ginger, onion and neemat three different concentrations (5\%,10\% and 20\%) amended with PDA were evaluated against the radial growth and mycelial dry weight of $F$. oxysporum. Among the four plant extracts, garlic extract at $20 \%$ concentration was highly effective to inhibit the radial growth of both the pathogen. The second highest reduction of $39.25 \%$ in radial colony growth was obtained with $20 \%$ neem extract and $40.41 \%$ in mycelium dry weight was attained with $10 \%$ garlic extract. Onion extract gave significantly lower reduction of radial colony growth and mycelial dry weight at all the concentrations in comparison to other extract. The highest concentration of ginger extract gave statically similar inhibition to the highest concentration of neem extract for both the radial colony growth and mycelial dry weight. In case of all the tested plant extracts the rate of reduction was significantly increased with increasing its concentrations except for neem extract where the inhibition of growth of the two higher concentrations was statistically similar. Result of the experiment showed that the most effective material is garlic, which was followed by neem, ginger and onion.

Based on findings of the present studies it may be concluded that:

i. Fourteen fungi comprising 12 genera were isolated from the selected 20 chickpea seed samples of which the pathogenic fungus Fusarium oxysporum was most predominant.

ii. The virulence of $F$. oxysporum was highly variable ranged from weak to highly virulent depending on the isolates.

iii. The antagonism of the isolates of $T$. harzianum were also variable against $F$. oxysporum

iv. In the laboratory evaluation, the antagonist $T$. harzianum isolates $\mathrm{T} 3$, Bavistin $50 \mathrm{WP}$ and Garlic extract at $20 \%$ were found to be most effective against theradial growth and mycelial dry weight of $F$. oxysporum. 


\section{References}

Ahmed, H.U. 1985. Abstracts of Research Papers of Plant Pathology Division. BARI. For the period, 1975-84. Bangladesh Agricultural Research Institute (BARI). Joydevpur, Gazipur. pp. 47.

Ahmed, H.U. 1985. Recommendations on Management of Crops in Bangladesh. Plant Pathology Division. Bangladesh Agricultural Research Institute (BARI). Joydevpur, Gazipur. pp. 65.

Anonymous.2004. Monthly Statistical Bulletin. Bangladesh Bureau of statistics, Statistic Division. Ministry of Planning, Govt. of the peopleôs of Bangladesh. P 54.

Barnet, H.L. 1980. Compedium of Soil Fungi. Burees Pub. Co. Minneapolis, U.S.A. 223p.

Dhingra, O.D. and Sinclair, J.B. 1985. Basics plant pathology methods. CRC Press. Inc. Boca Raton Florida. 13-44.

Gowda, C.L.L. and Kaul, A.K. 1982. Nutritional and Anti-nutritional Consideration. Pulses in Bangladesh. pp. 431.

Hossain, I. H., Ashrafuzzaman and Khan, M.H.H 1993. Biocontrol of Rhizoctoniasolani and Bipolarissorokiniana .BAU. Res. Prog. 7: 264269.

Khan, A.A. and Fakir, G.A. 1995. Seed treatment with garlic extract to control seed borne pathogens of jute. Bangladesh Journal of Plant Pathology.11:12.

Khan, M. A. A. 2003. Integrated management of seedling mortality of chickpea caused by Sclerotiumrolfsii. M.S. thesis, Department of Plant Pathology, Bangabandhu Sheikh Mujibur Rahman Agricultural University. P 85.

Merriman, P. and Russell, K. 1990. Screening Strategies for Biological Control. Biological
Control of Soil-borne Pathogens. Edited by D. Hornby, Published by C.A.B. International: $427-$ 435.

Nene, Y.L. and Haware, M.P. 1980. Screening of Chickpea for resistance to Wilt. Plant Disease 64: 379-380.

Nene, Y.L., Haware, M.P. and Reddy, M.V. 1981. Chickpea Diseases. Resistance Screening Techniques. Inf. Bul. 10. ICRISAT, Patancheru, AndraProdesh, India. pp 10.

Nene, Y.1., Sheila, V.K. and Sharma, S.B. 1996. A World List of Chickpea and Pegionpea Pathogens ( $5^{\text {th }}$ ed.). ICRISAT, Patancheru, AndraProdesh, India. pp. 27.

Rahman, M.A. and Ahmed, H.U. 1985. Screening of chickpea for resistant to Fusarium wilt. Bangladesh J. Plant Pathol. 1(1): 51-55.

Sing, K.B. and Dahiya, B.S. 1973. Breeding for Wilt Resistance in Chickpea. Pages 13-14 in Symposium on Wilt Problems and Breeding for Wilt Resistance in Bengal Gram, Sep. 1973, New Delhi, India: Indian Agricultural Research Institute.(Abstracts).

Strashnow, Y., Elad, Y., Sivan, A., Rudich, Y. and Chet, I. 1985. Control of Rhizoctoniasolani fruit rot of tomatoes by Trichodermaharzianum. Crop Protec. 4(3):359-364.

Sundar, A.R., Das, N.D. and Krishnaveni, D. 1995. In vitro antagonism of Trichodermaspp. against two fungal pathogens of Castor. Indian J. Plant Protec. 23(2): 152-155.

Suratuzzaman, M.I. Hossain, I. and Fakir, G.A. 1994. Control of seed-borne fungi of two rice varieties with some plant extract. Progressive Agriculture, 5 (1): 11-15. 